\title{
Modern aspects of managing the financial risks of an oil company in the context of globalization and global change
}

\author{
Margarita Mironova ${ }^{1,}$, Anna Romanova ${ }^{2}$, Danil Burkeev ${ }^{2}$, Bilyal Zaynutdinov $^{2}$, and Roza Safina ${ }^{2}$ \\ ${ }^{1}$ Kazan (Volga Region) Federal University, Institute of Management, Economy and Finance, Department of Corporative Finance, \\ Butlerova 4, 420012, Kazan, Russia \\ ${ }^{2}$ Kazan State University of Architecture and Engineering, Institute of Economics and Management in construction, Department of \\ Municipal Management, Zelenaya 1, 420043, Kazan, Russia
}

\begin{abstract}
.
Research background: Globalization is a process of uniting the world into a single system of global properties. The globalization of the world economy finds expression in the process of the global space being altered where it transforms into a single zone open to the free and unrestricted movement of goods, services, information and capital. The spread of the COVID-19 pandemic has disrupted the unification of economic life rules and the transformation of the system of interstate regulation of global economic cooperation. There has been a disruption in technological, logistics and business chains resultant from the world's leading national economies closing and many economic entities which operated in the "real economy" shutting down. These "pandemic-caused" factors have put substantial restrictions on the income of companies and their staff while also fueling unemployment.

Purpose of the article: to research the company's financial risks in the context of global changes caused by the pandemic.

Methods: The study employs methods of analysis and synthesis, statistical data analysis as well as regression analysis.

Findings \& Value added: The main goal of the research is to study the main types of financial risks of an oil company, analyze the econometric model, and identify the main factors that affect the company's solvency in the context of global changes.
\end{abstract}

Keywords: globalization; financial risks; company's solvency; global changes

JEL Classification: $C 51 ; D 21 ; G 32$

${ }^{*}$ Corresponding author:marg.mironova2011@yandex.ru 


\section{Introduction}

Towards the end of the twentieth century, rapidly evolving technological, economic, political, cultural, environmental and social processes among others ushered in a new era termed by scientists as the era of globalization. The essence of it lies in the economic, political and cultural life of national states theretofore fragmented being woven into a single "planetary ball" along with humanitarian challenges and social and economic processes acquiring mutual nature for most states. The hallmark of modern communications is that anything anywhere in the world can be reached through the global Internet and contemporary modes of transportation.

Globalization of the world economy finds expression in the process of the global space changing where it is transforming into a single zone open to unobstructed movement of goods, services, information, and capital. The global space facilitates the spread of ideas with their carriers moving around with ease thereby contributing to the development of relevant institutional entities and putting in place systems to ensure interaction between them.

The product of globalization is the emergence of a single cultural, informational, legal and economic environment at the global level. That being said, the process of globalization as it pertains to the development of economic, cultural, political, and information integration is not completely characterized by a homogeneous "ascending" trend. Research into the processes of globalization proceeding from the example of world trade development have pointed to there having been at least three waves of globalization since 1795[1]. The authors of the research have noted a significant feature of the contemporary process of globalization that is structural globalization which is characterized by the increasing density of large-scale networks of interaction all over the world as compared to the density of smaller networks [1].

The spread of the Covid-19 pandemic has given rise to processes which run counter to globalization. Globally, the world has been witnessing de-globalization for several years now, at least when it comes to aspects directly linked to international business and trade. Slackening interdependence in these two dimensions implies that states are less dependent on goods and services or on investments coming from other states as compared to domestic economic activity levels. "In other words, trade and investment flows as percentages of GDP should be declining" [1].

The unified rules of economic life have been disrupted with the system of interstate regulation of world economic relations undergoing a transformation. De-globalization has turned into an undeniable reality bringing about a significant qualitative shift in strategies, structures and patterns of behavior observed across international businesses [2]. The usual definition of globalization is that of a process of growing interdependence between states which implies that deglobalization is the process of degrading interdependence between states [3]. The growth of globalization, however, has caused a negative attitude of the population of many countries. Unfortunately, in popular narratives, globalization has been associated with a new geography of discontent - mostly devoid of a sound factual basis. Such discontent is driven by perceptions of alleged, undesirable societal effects. Even individuals in geographic locations enjoying net efficiencybenefits from globalization appear to experience discontent [4].The world going on lock-down has resulted in leading national economies experiencing a disruption in technological, logistic and business chains along with a large number of economic entities which operated in the "real economy sector" being forced to suspend operations. These "pandemiccaused" factors have substantially curtailed the incomes of businesses and those of their personnel adding to unemployment. In the context of globalization, the increasingly complex process of management decision-making has led companies to break their activities up in subtle ways to have each clearly defined functional area in the right place which serves to deepen the international division of labor [5]. Decision-makers at multinational enterprises are now pursuing various measures to mitigate the impact of the pandemic. These activities are mostly in some way connected to distance management and redefining boundaries whether it is at the macro level or at the corporate level [6]. The global challenges facing top managers these days come down to management in an environment of uncertainty, promotion of international and even global activities, and reviews of corporate efficiency which have now come to the fore in terms of management-related decisions which determine the future of both multinational and national companies across various industries $[7,8]$.

In the context of the modern market, the ability to identify and manage arising financial risks represents an essential factor to ensure the successful development of a business. The current unstable economic and political global situation is forcing companies to place particular emphasis on the system of financial risk management and minimization. One of the key sectors adversely affected by the current situation in terms of economic activity is that of oil and gas companies. Oil exports and oil export revenues are given in the graphs (Fig. 1 and Fig. 2). 


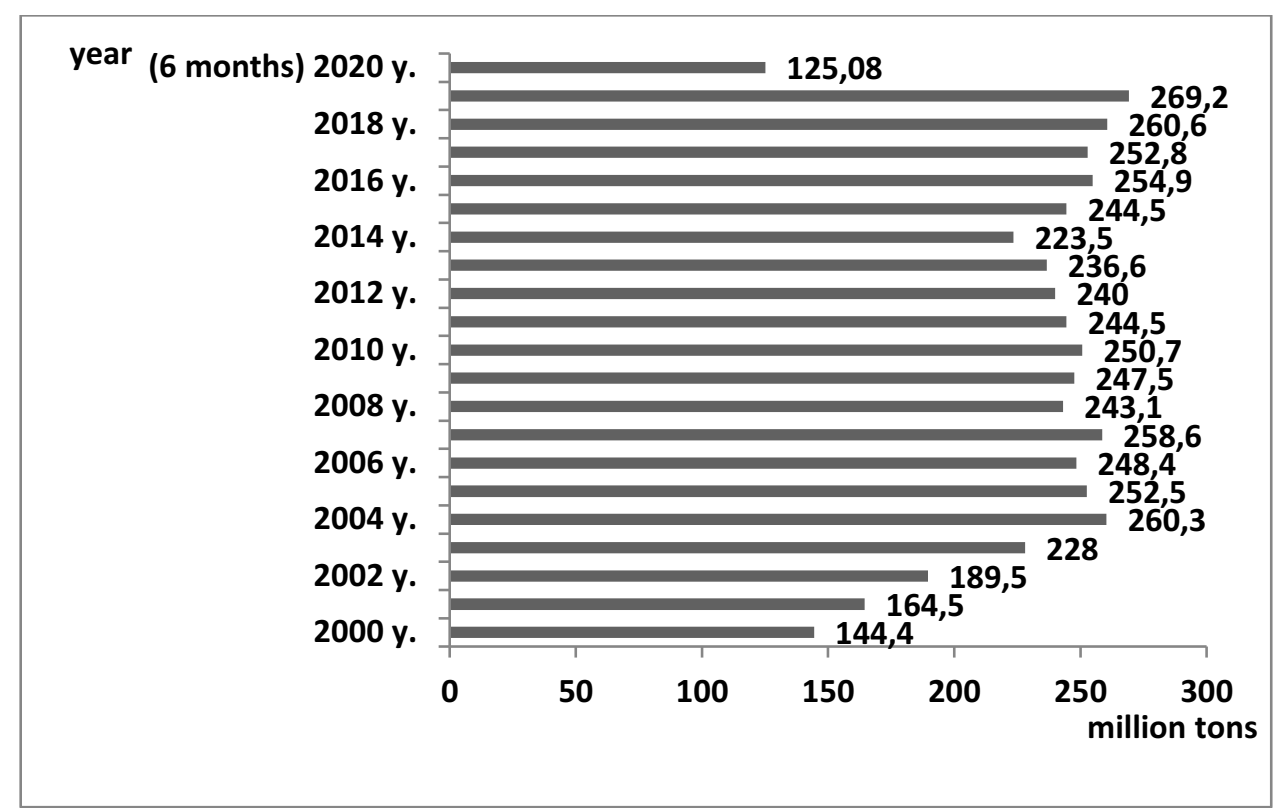

Fig. 1. Oil exports from Russia year-wise (million tons); data provided by the Federal Customs Service and the Federal State Statistics Service

Source: [9]

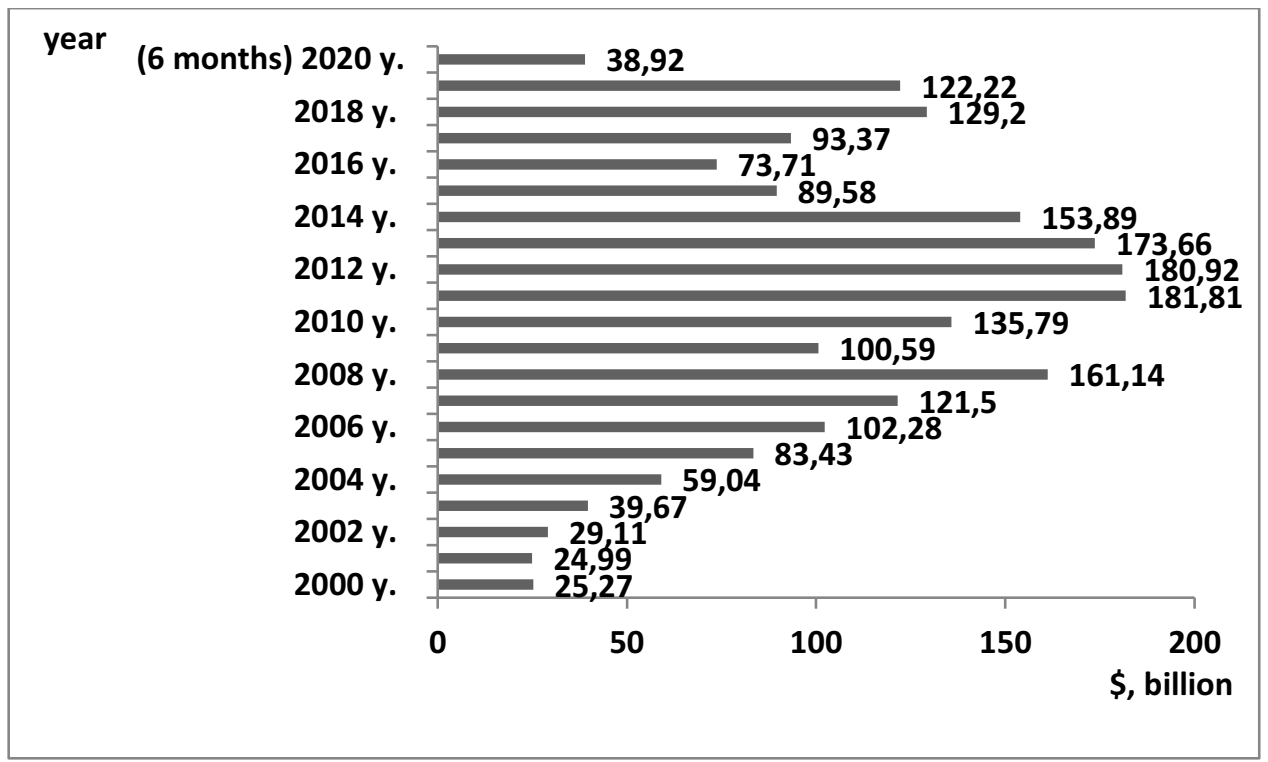

Fig. 2.Russian oil export revenues (in billions of dollars); data provided by the Central Bank of the Russian Federation Source: [9]

The growing currency rate against the ruble, the drop in oil prices per barrel when Russia withdrew from the OPEC+ agreement in early 2020, the global epidemiological situation and the reduced demand for oil products which ensued all these factors pose threats to the businesses of companies by undercutting their financial standing and solvency.

The operations of oil and gas companies tend to be exposed to various risks which are likely to produce an adverse impact on production and financial performance. Companies seek to lessen the risks which are under their control while not losing sight of the potential negative effects of risks over which they have no control.

The oil industry is the backbone sector of the Russian economy which incorporates the whole cycle of production, processing, shipping, storage and sale of oil and its derivatives. Over the past decade and a half, Russia has seen an annual increase in oil production volumes. By 2016, there was so much oil being produced in Russia that it got to be the world's leading oil exporter surpassing even Saudi Arabia.

Russia is among the top three world leaders in oil production (along with the United States and Saudi Arabia). In 2018, Russia produced 555.9 million tons of oil and gas condensate; $1.7 \%$ more than in 2017 . This boost in production in the Russian Federation happened owing to the decision made in June 2018 by the OPEC + member-states to allow a partial increase of oil production to compensate for deficient supply (and anticipated US sanctions against Iran) in the oil market.

An analysis of the reports of leaders in oil production and refining has identified the following financial risks typical for companies which operate in that sector: 
1. Market risks including price risks, currency risks and interest rate risks.

2. Repayment risks under contracts for supply of oil, petroleum products, gas, gas processing products and petrochemicals.

3. Liquidity and solvency risks.

All of the risks listed above have an impact on corporate financial performance directly affecting the liquidity and solvency levels of a business. The high volatility of prices for hydrocarbons and products produced from these, currency rates, climbing rates and fees of suppliers and other externalities may generate imbalance in the outcomes of plans, budgets and investment programs thus leading to deficient liquidity and scanty sources of funding.

Macroeconomic risks beyond the control of businesses are also to be factored in. The coronavirus epidemic began its spread around the globe in late 2019. Measures adopted all around the world to curb the spread of COVID-19 give rise to the need to impose restrictions on business activity, which affects demand for energy resources and other products supplied by companies as well as the need to design and put in place measures geared at maintaining good management practices in an environment of uncertainty, promoting international and even global activities and reviewing corporate efficiency [10]. Besides that, the OPEC + deal intended to limit oil production failed to be extended in March 2020 losing effect as of April 1,2020, which made room for various oil-producing states to add to the supply of oil and oil products on the market. This was accompanied by a significant drop in stock markets with commodity prices declining, in particular, oil prices. At the same time, the Russian ruble lost substantial ground to the US dollar and the Euro and lending rates spiked for many businesses operating in emerging markets. The crisis worsened the efficiency and long-term equilibrium of the crude oil market. [11, 12]. The OPEC report said that "Future demand will likely remain persistently below past projections due to the lingering effects of the Covid-19-related shutdowns and their impact on the global economy and consumer behavior" [13].

\section{Methods}

At the outset of the study we hypothesized that effective financial risk management positively impacts the solvency of companies. Four major Russian oil and gas companies were selected for the study, to name: PJSC Tatneft, PJSC LUKOIL, JSC NovaTEK and JSC Gazprom Neft. The information sampled included quarterly data for the period of 2013 - 2019.An econometric study was carried out involving an econometric model which was constructed to put the hypothesis to the test which proved that there is a relationship between the given variables and the solvency of companies. An adjusted model was constructed through sequential exclusion of factors from the model as it was being checked for multicollinearity, that is, the factors viewed as insignificant for the model and collinear were excluded (Table 1).

Table 1.Adjusted estimate of the least-squares model

\begin{tabular}{|c|c|c|c|c|c|}
\hline & Coefficient & Standard error & t-statistics & P-value & Significance value \\
\hline const & 19.2822 & 1.07289 & 17.97 & $<0.0001$ & $* * *$ \\
\hline $\mathrm{X} 1$ & -0.0236305 & 0.00472772 & -4.998 & 0.0008 & *** \\
\hline $\mathrm{X} 2$ & 3.42484 & 1.00842 & 3.396 & 0.0010 & $* * *$ \\
\hline $\mathrm{X} 3$ & 0.100337 & 0.0345472 & 2.904 & 0.0069 & $* * *$ \\
\hline $\mathrm{X} 4$ & -0.251845 & 0.0466045 & -5.404 & $<0.0001$ & $* * *$ \\
\hline $\mathrm{X} 5$ & -0.445316 & 0.0684558 & -6.505 & $<0.0001$ & *** \\
\hline X6 & 0.225471 & 0.0730916 & 3.085 & 0.0026 & *** \\
\hline $\mathrm{X} 7$ & -13.7692 & 0.607612 & -22.66 & $<0.0001$ & $* * *$ \\
\hline & uare & 0.872118 & \multicolumn{2}{|c|}{ Corrected R-square } & 0.863166 \\
\hline \multicolumn{2}{|c|}{$\mathrm{F}(5,102)$} & 97.42401 & \multicolumn{2}{|c|}{ P-value (F) } & $9,08 \mathrm{e}-42$ \\
\hline & & & \multicolumn{2}{|c|}{ Stat. Durbin-Watson } & 1.9203 \\
\hline
\end{tabular}

Source: compiled by the authors in Gretl

All variables incorporated in the adjusted model are $99 \%$ significant. The determination coefficient leans towards the value of 1 with the current value standing at $87.2 \%$. The Fisher's criterion shows that the model is significant.

The linear multifactor regression model is formed as follows:

$$
\begin{gathered}
y=19,28-0,0236 \ln (\text { Price })+3,425 R_{p r}+0,1 K_{\text {pokr }}-0,252 \ln \left(K_{\text {act }}\right)-0,445 K_{\text {deb }} \\
+0,225 K_{\text {kred }}-13,769 K_{\text {avt }}
\end{gathered}
$$

The analysis carried out shows that the degree of solvency is affected by: oil prices (Price, X1), return on sales (Rpr, $\mathrm{X} 2$ ), coverage ratio (Kpokr, X3), turnover rate of receivables (Kact, X4) turnover rate of payables (Kdeb, X5), equity to total assets ratio (Kavt, $\mathrm{X} 6$ ). 


\section{Results}

As indicated earlier, the leading financial risks of oil and gas companies include currency risks, price risks, liquidity risks and repayment risks. The variables incorporated into the model directly reflect the impact of these financial risks on the overall degree of solvency and, in consequence, corporate financial sufficiency.

It is therefore safe to say that the hypothesis about the impact of financial risks upon the degree of solvency is correct and further substantiated by the econometric model. In view of this, effective management of corporate financial risks produces a positive impact on such indexes as oil prices, return on sales, the coverage ratio, the turnover rate of receivables, the equity to total assets ratio which in turn has a bearing upon the overall degree of corporate solvency.

It makes sense to integrate data related possible sources of origin of financial risks and apply the comprehensiveness principle whilst carrying out analytical work in order to drive up the efficiency of assessments of the impact produced by financial risks upon the operations of businesses. Proceeding from this premise, guidelines must be developed and put in place to serve the function of assessing the financial risks of companies in the oil and gas sector.

The comprehensive nature of such guidelines is backed up by following major segments: input and output data and analyses of financial performance. Below is a more detailed look at the stages defined for development of guidelines.

Stage 1. With inflation, currency and interest-rate risks defined as the dominant financial risks following the analysis conducted under the study, the indicators of the first section include: exchange rate of the ruble to the world currency; inflation rates; credit interest rate.

Stage 2. An assessment of the impact produced by financial risks on the operations of businesses by relying on financial indicators. This stage involves a rapid assessment of the financial standing of a relevant business.

When constructing a financial model, the focus must be on accounting for the possibilities available to analyze financial risks and to reflect correctly the dependency factors identified and analyzed at Stage 3.

The financial risk management techniques selected determine the ways to lessen the risks identified. Addressing this issue calls for expertise in the field of financial risk management, including knowledge of financial risk hedging tools available on the market. Acquiring information on financial risk management/hedging tools may call for experts from companies which provide such tools, or independent consultants with appropriate expertise.

Financial risk management results are assessed based on fiscal financial performance or following the completion of significant financial transactions. Below are significant tools to be used to ensure effective assessment of financial risk management outcomes: planned/actual analysis of forecast operational and macroeconomic performance indicators; planned/actual analysis of how financial risk management recommendations are being implemented; updating the financial model with due regard for changes in forecasts of macroeconomic and operational indicators.

\section{Discussion}

The analysis of the financial performance of a major Russian oil-producing company Tatneft (based in the Republic of Tatarstan) has been used by us as the basis for constructing and studying an econometric model of corporate solvency. The following primary factors affecting this indicator have been identified, to name: oil prices per barrel, return on sales, coverage ratio, net assets, turnover rate of receivables, turnover rate of payables, equity to total assets ratio. Research has indicated that if the current trend persists, changes in indicators have a negative, but not critical impact upon the financial standing state of the company in question (i.e. one that does not result in bankruptcy). Improving solvency requires the company to ramp up profitability by increasing revenues or cutting down costs. However, this is difficult to accomplish in the context of the current economic situation as the financial performance of oil companies depends on oil prices and the exchange rate.To summarize the information obtained, it is safe to say that PJSC Tatneft is exposed to the following financial risks: currency risks, price risks, liquidity and solvency risks, repayment risks and interest rate risk. The company must take the following steps to minimize the negative impact of these risks:

1. Manage currency risks by employing a comprehensive approach, including hedging and geographical diversification. Analyze the risk exposure of changes in interest rates, including by modeling various scenarios to assess the influence of interest rate changes upon financial performance.

2. Monitor liquidity indexes on a regular basis along with assessing the sensitivity of indexes related to plans, budgets and investment programs to changes in macroeconomic indexes.

3. Apply a flexible commodity supply management system allowing for quick response to changes in the market structure and carrying out arbitrage shipments; hedge operations while going about international trading activities.

\section{Conclusion}

According the simple observation remains that most of even the world's largest firms are incapable of emulating the same level of home region success (as measured by sales and asset levels) throughout the world, because "distance" does continue to matter [14]. The formation of cross-border financial flows is inevitably subject to financial risks of a more diverse nature and impact than when a company operates within a single country. Therefore, financial risk management should be viewed as a process aimed at identifying and taking effective actions which render financial risk acceptable. Financial risk management can be viewed as a process of alternative selection and presentation of an identified risk encompassing neutralizing the risk factor, lessening the risk of adverse events arising, minimizing negative scenarios in 
the event of risk events, transferring risks or distributing them among several stakeholders/business entities; accepting risks and approving measures to address its effects. The Coronavirus crisis has massively aggravated the existing systemic risks facing the international order. Changes in the global economy caused by the COVID 19 pandemic have changed the structure of the external and internal environment of companies. As noted Mayer and Gereffi private governance will be linked to emerging forms of multi-stakeholder institutions [15].New challenges have arisen that require management decisions aimed at building new remote communications with external and internal stakeholders, introducing structural changes, including at the level of the company's organizational culture. The modern education system faces these challenges. Reality shows that creativity as the ability to make non-standard decisions should be a vital professional competence of modern managers [16]. Management decisiveness must be combined with flexibility in decisions. All the efforts of managers in the face of global challenges should be aimed at creating such changes in the company's management system that will contribute not only to its survival, but also to its further growth.

The work is performed according to the Russian Government Program of Competitive Growth of Kazan Federal University.

\section{References}

1. Chase-Dunn, C., Kawano, Y., Brewer, B.D. (2000). Trade globalization since 1795: Waves of integration in the world-system. American Sociological Review, 65(1), 77-95.

2. Witt, M.A. (2019). De-globalization: Theories, predictions, and opportunities for international business research. Journal of International Business Studies, 50(7), 1053-1077.

3. Coeurderoy, R., Murray, G. (2008).Regulatory environments and the location decision: Evidence from the early foreign market entries of new-technology-based firms. Location of International Business Activities. Journal of International Business Studies, 39(4), 670-687.

4. Verbeke, A., Coeurderoy, R., Matt, T. (2018). The future of international business research on corporate globalization that never was. Journal of International Business Studies, 49(9), 1101-1112.

5. Buckley, P.J., Ghauri, P.N. (2004). Globalisation, economic geography and the strategy of multinational enterprises. Journal of International Business Studies, 35(2), 81-98.

6. Petricevic, O., Teece, D.J. (2019). The structural reshaping of globalization: Implications for strategic sectors, profiting from innovation, and the multinational enterprise. Journal of International Business Studies, 50(9), 14871512.

7. Caligiuri, P., De Cieri, H., Minbaeva, D., Verbeke, A., Zimmermann, A. (2020). International HRM insights for navigating the COVID-19 pandemic: Implications for future research and practice. Journal of International Business Studies, 51(5), 697-713.

8. Mironova, M., Markova, S., Zapparova, Z., Kameneva, E. (2018). Contents and Ways of Organizational-Financial Risks Reduction among Managing Subjects in Housing and Utility Service. Helix, 8(1), 2522-2526.

9. Thompson, H. (2020, April 23). Low demand for oil isn't good news. It could cause a financial crisis. The Guardian. https://www.theguardian.com/commentisfree/2020/apr/23/low-demand-oil-financial-crisis-us-debt-global-economy

10. Joo, K., Suh, J.H., Lee. D., Ahn, K. (2020, July 30).Impact of the global financial crisis on the crude oil market. Energy Strategy Reviews. URL:https://http//www.elsevier.com/locate/esr.

11. Ambrose, J. (2020, October 08). Opec rejects projection that global demand for oil has peaked. The Guardian. https://www.theguardian.com/business/2020/oct/08/opec-rejects-projection-that-global-demand-for-oil-has-peaked.

12. Federal state statistics service of the Russian Federation. Official statistics. https://rosstat.gov.ru/folder/10705.

13. Verbeke, A. (2013). International Business Strategy. Cambridge University Press.

14. Aitchison, G., Cooper, L. (2020, June, 24). Coronavirus and the crisis of globalisation: dangers and answers. OpenDemocracy. https:/www.opendemocracy.net/en/can-europe-make-it/coronavirus-and-crisis-globalisationdangers-and-answers/.

15. Mayer, F., Gereffi, G. (2010). Regulation and Economic Globalization: Prospects and Limits of Private Governance. Cambridge University Press, Business and Politics, 12(3), 1-25.

16. Mironova, M., Bushueva, A. (2019). Creativity as a professional skill of the manager in the era of globalization. Ad Alta: Journal Of Interdisciplinary Research, 9(2), 37-40. 